\title{
Disturbing the Past and Jeopardising the Future: Retrospective and Prospective Overruling
}

\author{
Professor Johannes Chan \\ Dean, Faculty of Law \\ The University of Hong Kong
}

Unlike legislation, judicial judgments normally have retrospective and prospective effect. By necessity, every judicial decision is dealing with events that have taken place in the past, and the court is trying to apply the law as it has found to be at the time when those events took place. At the same time, judges do not create law. They declare what the law has always been and will be, at least insofar as the declaratory theory of law is accepted. Hence, the judgment represents the law as it always is, and the law that will continue to apply to the future, a consequence that is fostered by the doctrine of precedents.

These principles work well in the normal circumstances, but what if a declaration of illegality of a Government act or unconstitutionality of a statutory provision would have drastic consequences for the community? Such drastic consequences may take the form of disturbing or even reversing a long line of previous judicial or administrative decisions, or resulting in a legal vacuum such that it would be very difficult or even impossible for the Government or law enforcement agencies to continue to operate satisfactorily. This gives rise to the controversial issue of how far the courts can limit the temporal effect of its judgments so as to avoid disturbing past decisions or creating a legal vacuum in the future before necessary remedial measures can be taken. ${ }^{1}$ On the one hand, a fundamental aspect of

\footnotetext{
$1 \quad$ This article was partly based on a previous article that has appeared as Johannes Chan, 'Some Reflections on Remedies in Administrative Law' (2009) 39 HKLJ 321-337. For further discussion, see also Chief Justice Li, 'Reflections on the Retrospective and Prospective Effect of Constitutional Judgments', in Rebecca Lee (ed), Common Law Lectures 2010 (Faculty of Law, The University of Hong Kong, 2011), pp 2155; Kevin Zervos, 'Constitutional Remedies under the Basic Law' (2010) 40 HKLJ 687-718. For an earlier debate, see PA Joseph, "Constitutional Law” [2006] NZ Law Review 123 at 138-149; Shannon, "The Retrospective and Prospective Application of Judicial Decisions (2003) 26 Harvard Journal of Law \& Public Policy 811; A Mason, “ Prospective Overruling” (1989) 63 Aust LJ 526.
} 
the rule of law is that any Government act must be lawful, and any legislation has to be constitutional. On the other hand, in administrative law, remedies are always discretionary. The court may shape or even refuse to grant remedy if doing so would cause undue disruption to good public administration. ${ }^{2}$ How far this discretion could go to restrict the effect of its judgment to the future or to allow an otherwise unlawful act or statutory provision to continue to apply, notwithstanding a declaration of illegality, and how should this discretion, if it exists in the first place, be exercised? The existence and the extent of this discretionary power go to the very basis of the doctrine of separation of powers, and it is not surprising that different jurisdictions have adopted different solutions to this problem.

In dealing with the burden of the past, it has been suggested that the court should have power to make prospective overruling so that past decisions would not be disturbed, and in avoiding a future legal lacuna, it has been argued that the court may suspend its declaration of invalidity or grant temporary validity to the offending law. While at first sight they seem to be powers of different nature, it is argued that they are in fact the two sides of the same coin. In either case, the court is putting a temporal restriction on its judgment such that its judgment would only come into effect at the time of the judgment (with a caveat that it applies to the case before the court) or it would only come into effect at some specified time in the future. The principle should be the same, whether the court is dealing with the past or the future. It is further argued that there is no practical distinction between an order staying the effect of a declaration of invalidity and an order conferring temporary validity to the offending law. The same principle applies and the power of the court should only be exercised in the most extraordinary circumstances. Despite judicial caution of the exceptional nature of this power, the experience in Hong Kong and Canada seems to point to a fairly liberal application.

\section{Disturbing the Past}

This issue first arose in Hong Kong in $R v$ Kwok Hing Man. In that case, the applicant was convicted of an offence of unlawful possession and had served his sentence. This

\footnotetext{
$2 \quad R v$ Monopolies and Mergers Commission, ex p Argyll Group Plc [1986] 1 WLR 763; Caswell v Dairy Produce Quota Tribunal [1990] 2 AC 738.
} 
offence was found first by the Hong Kong Court of Appeal and later by the Judicial Committee of the Privy Council to be inconsistent with the right to presumption of innocence under the Bill of Rights and hence unconstitutional. Hence, the offence was struck down by the Bill of Rights at the time when the Bill of Rights came into operation, namely 8 June 1991. The applicant was convicted after 1991. The decision of the Privy Council was made in 1993. The applicant applied to expunge his record of criminal conviction. It was found that between 1991 and 1993, 364 persons were convicted of this offence. The Attorney General argued forcefully that there must be finality in the criminal justice system. Any retrospective overruling would create unacceptable uncertainty to the criminal justice system. There was a technical way out. The time limit for appeal for these cases has long expired. Thus, the court could simply have refused to exercise its discretion to allow an extension of time for appeal. Instead, the Court of Appeal adopted a rather unusual move of consulting all members of the Court of Appeal, and decided that, as a matter of legal policy, the Court would grant an extension of time to appeal in such circumstances, thereby expunging 364 criminal convictions.

The same problem arose outside the criminal field in the aftermath of Lam Siu Bov Commissioner of Police. In that case, Mr Lam challenged the restriction in the Police (Disciplinary) Regulation that a police officer was not permitted to have legal representation in disciplinary proceedings unless the legal representative was also a member of the Police Force. There were only a small number of police officers who were legally qualified, and even fewer of them were prepared to act for police officers in disciplinary proceedings which were normally chaired by a Police Superintendent, as the legal representative would inevitably have to challenge senior police officers in the course of defence in a culture where strict obedience to the orders of the senior officers is the expected behavior in the disciplinary force. The Court of Final Appeal struck down this restriction for being a violation of the right to fair hearing under Article 10 of the Bill of Rights.

As a result of the CFA judgment in Lam Siu Po, many police officers sought to reopen and overturn their disciplinary convictions on the ground that they had been denied legal representation. In most of these cases, the application for leave to apply for judicial 
review, ${ }^{3}$ or if leave had previously been granted, an application to include a new ground to take advantage of the decision in $\mathrm{Lam} \mathrm{Siu} \mathrm{Po}^{4}$, or an application for an extension of time to appeal to the CA or CFA on the basis of Lam Siu Po, ${ }^{5}$ were lodged long out of time. The courts had not been entirely consistent in handling these applications. ${ }^{6}$ The matter was eventually resolved by the CFA in Clarence Chan $v$ Commissioner of Police in favour of finality of litigation. ${ }^{7}$ It was held that the mere fact that the law has been changed in favour of a litigant who had previously lost on that view of the law was not a sufficient reason to justify an extension of time for appeal. Such extension could only be justified on very rare occasions of exceptional circumstances.

While the issue was resolved by a refusal to exercise discretion to grant an extension of time for appeal, the aftermath of Lam Siu Po highlights the problem of retrospective operation of the common law. It is an inherent feature of the common law that the court in deciding a case is necessarily applying the principle to some events in the past, and hence the common law, by necessity, operates retrospectively. This poses a major challenge to our system of justice when a settled principle of law is reversed, as there may be numerous past decisions or actions that were based on the previous erroneous view of the law and may potentially be open to challenge, sometimes long after the decisions had been made. In the normal course of events, the time limit for filing a case or lodging an appeal will take care of the situation, but the situation becomes more complex when the vires of the source of power is successfully challenged. In Kwok Hing Man, 364 criminal convictions have to be set aside when many of them have already served their sentence. In the Lam Siu Po aftermath, numerous police officers tried to re-open their disciplinary convictions. It is true that the latter line of cases could be distinguished from Kwok Hing Man in that the police officers were convicted only of a disciplinary offence whereas in Kwok Hing Man, the defendants

\footnotetext{
3 See Tsui Kin Kwok Johnnie v Commissioner of Police, HCAL 50/2009; Yiu Sung Chi \& Lam Yau Tak Joseph v Commissioner of Police, HCAL 101 \& 102/2009); Tsui Chun Fai Danny v Commissioner of Police, HCAL 131/2009); Li Kin Wah \& Yung Kam Cheung, HCAL 126/2009 \& 6/2010); Wong Chi Keung \& Others $v$ Commissioner of Police, HCAL 1/2010, HCAL 20/2010 \& HCAL 21/2010).

$4 \quad$ Chiu Kin Ho v Commissioner of Police, HCAL 135/2004.

$5 \quad$ Ho Ho Chuen v Commissioner of Police, HCMP 2276/2009; Chan Kang Kau Clarence v Commissioner of Police, HCMP 2824/2004).

$6 \quad$ Leave to make an application or appeal out of time was granted in Chau Cheuk Yiu v Poon Kit Sang, HCMP 121/2010; Chan Ka Man v Commissioner of Correctional Services, HCAL 111/2009. The Chief Justice explained these decisions as turning on the peculiar facts of these cases and did not decide any principles of law: see Chief Justice Li, 'Reflections on the Retrospective and Prospective Effect of Constitutional Judgments', in Rebecca Lee (ed), Common Law Lectures 2010 (Faculty of Law, The University of Hong Kong, 2011), p 21, at p 44.
}

FAMV No 15 of 2010; affirmed in Lam Chi Pan v Commissioner of Police, FAMV 35 of 2010. 
were convicted of a criminal offence where liberty of the person was at stake. While this may offer a plausible basis for distinction, the irony is that in many convictions in the Kwok Hing Man situation, the defendants were given a small fine only, whereas in the police officers cases, a disciplinary conviction would almost inevitably lead to dismissal from the Police Force and a consequential loss of very substantial pension benefit.

The correctness of the decision in Kwok Hing Man was challenged in HKSAR v Hung Chan $\mathrm{Wa}$. In that case, the defendant was convicted of an offence of unlawful possession of dangerous drug on the basis of a reverse onus provision, under which he has the legal burden to rebut a presumption of possession when he was proved to be in possession of the key of certain container in which the drug was found. In Hung Chan Wa, it was held that this reverse onus provision was a violation of the right to presumption of innocence under the Bill of Rights, but that this reverse onus provision could be upheld by construing this provision to impose an evidential as opposed to a legal burden of proof on the part of the defendant. The prosecution urged the court to make this declaration with prospective effect only so that defendants who were convicted of this offence in the past would not be affected. The Court of Appeal doubted if the court has the power to make prospective overruling, whereas the Court of Final Appeal was prepared to assume, without deciding, that it has an inherent power to engage in prospective overruling. ${ }^{8}$ The Court of Final Appeal recognized that this question might depend on the understanding and the extent of separation of powers and the particular relations between the Legislature, the Executive and the Judiciary in different jurisdictions, and as a result, this was not a question that might yield to a common answer in different parts of the common law world. With such riders, Li CJ provided a helpful summary of the exercise of such power if it existed. He held that (1) if such a power exists, it is an extraordinary power that the court would approach its exercise with the greatest circumspection; (2) whether this power exists depends on the particular constitutional framework of the jurisdiction concerned, and there may not be a common approach across the common law world; (3) the existence and scope of such power may vary in different situations, as the same considerations do not apply to all situations in the different context of private law, criminal law or public law; (4) the existence of the power may also be dependent on the range of remedies that may be available; and (5) common law is developed by an

\footnotetext{
8 HKSAR v Hung Chan Wa (2006) 9 HKCFAR 614; Koo Sze Yiu v Chief Executive (2006) 9 HKCFAR
} 441. 
evolutionary process and such development cannot be regarded as an application of the power to prospectively overrule. ${ }^{9}$

Despite this obiter, the Court of Final Appeal preferred to approach the matter on whether extension of time to appeal should be allowed. It held that finality and certainty were of great importance, and an extension of time should not be granted merely on the ground that an authoritative judgment subsequent to the conviction has held that the previous understanding of the law was incorrect. There might be exceptional circumstances where an extension of time to appeal as a result of a subsequent reversal of previous law, but these would be the exceptional cases and this regard, it expressly reserved its view on the correctness or otherwise of Kwok Hing Man to a future occasion when the issue arose.

Notwithstanding this reservation, it is argued that Kwok Hing Man must still be good law. It is accepted that finality and certainty are great and important social values in the legal system. It would be particularly inappropriate to grant an indulgence where a defendant acting on advice had pleaded guilty or where he had taken a conscious and informed position not to appeal. ${ }^{10}$ Dixon CJ adopted a harsh position when he explained it in Victorian Stevedoring and General Contracting Co Pty Ltd v Dignan, " If [a defendant] has been convicted, then because his liability has merged in the conviction, it no longer depends upon the law under which it arose, and it does not lapse with the revocation of the law. The conviction has become the source of his liability for his offence, and the conviction continues in force because its operation does not depend upon the law creating the offence, but upon the authority belonging to a judgment or sentence of a competent court."11 Perhaps the sentiment is best captured by Lord Bingham CJ, "The practice may on its face seem harsh. On the other hand, the consequences of any other rule are equally unattractive. It would mean that a defendant who had roundly on advice accepted that he had acted dishonestly and fraudulently, and pleaded guilty, or who had been found guilty and chosen not to appeal could after the event seek to reopen the convictions. If such convictions were to be readily reopened it would be difficulty to know where to draw the line or how far to go back." ${ }^{2}$ Likewise, the Canadian courts also adopted a fairly rigid approach under which leave to allow an extension of time in such situation would only be allowed if the defendant was still in the judicial

HKSAR v Hung Chan Wa (2006) 9 HKCFAR 614 at 634.

See $R v$ Ballinger [2005] Cr App R 433, per Scott Baker LJ, at 437-438.

(1936) 46 CLR 73, adopted in $R v$ Unger [1977] 2 NSWLR 990.

$R v$ Hawkins [1997] 1 Cr App R 234, at 240B 
system, and accepted that there was no perfect justice such that a defendant should not artificially be brought into the system. ${ }^{13}$

Nonetheless, the court did accept that there could be exceptional cases where justice may demand an extension of time for appeal because the law justifying the appeal was subsequently found to be incorrect. ${ }^{14}$ The burden is on the defendant to show that some special feature or features particular to the case would lead to the conclusion that leave ought to be granted. Kwok Hing Man may fall into this special category of cases. While this decision would have the disturbing effect that all criminal convictions may be potentially set aside if the offence of the conviction was successfully challenged to be unconstitutional many years after the conviction, it will be an affront to any sense of justice to uphold the conviction of people of an unconstitutional offence, and even more so to continue to remand a person in custody for an offence that has transpired to be unconstitutional and non-existent. ${ }^{15}$ Likewise, it would be an uncomfortable situation if repealing some unconstitutional provision may expose someone at risk of being convicted of a criminal offence that he would otherwise not have committed. ${ }^{16}$

In all these cases, the court has left open the central issue of whether the court has jurisdiction to make prospective overruling and whether prospective overruling could be a proper technique to avoid the problems of having a large number of cases applying to re-open their past convictions.

\section{Suspension of Declaratory Relief}

A different scenario is that instead of disturbing the past, a declaration of unconstitutionality would lead to a chaotic situation by creating a legal lacuna. The issue here then is whether a court could suspend its declaratory relief in order to give time for the Government to remedy the situation, but in the meantime to allow the continuation of the

\footnotetext{
$13 \quad R v$ Wigman [1987] 1 SCR 246 at 257; $R v$ Thomas [1990] 1 SCR 713 at 716.

$14 \quad$ Alofa $v$ Department of Labour [1980] 1 NZLR 139 at 146, per Cooke J, "at least special circumstances must be shown to justify a departure from the principle of the finality of the results of court proceedings."

$15 \quad$ See also $R v$ Governor of Brockhill Prison, ex parte Evans (No 2) [2001] 2 AC 19 at 37 where the court observed, "If ever there was a case where the declaratory theory should be applied it must surely be one where the liberty of subject is in issue - as it plainly is where the point relates to the entitlement of the subject to be released from custody." Also Re Spectrum Plus Ltd [2005] 2 AC 680 at 696, paras 26-27, per Lord Nicholls. $16 \quad$ This may happen when a defence was found to be unconstitutional. One example would be the striking out of the defence of marriage as consent to marital rape.
} 
unconstitutional law to continue to operate. It is well known that the court can take into account the demand of good public administration in determining whether to exercise its discretion to grant remedies in judicial review. ${ }^{17}$ How far can a court allow an executive act to take legal effect when it is based on a statutory provision that the court has concluded to be unconstitutional? This question arose in Koo Sze Yiu v Chief Executive. ${ }^{18}$ For many years, the Government had relied upon s 33 of the Telecommunication Ordinance for conducting covert surveillance. This section was heavily criticized for its excessive breath. A private member's bill was introduced in 1997 to amend this section against the will of the Government, and the Government did not bring the amendment into force. It was only when the courts refused to admit evidence obtained by covert surveillance in some criminal cases that the Government was prepared to introduce, by way of an Executive Order, a tightened authorization and review procedure. ${ }^{19}$ Both the Court of First Instance and the Court of Appeal found s 33 a violation of the right to private communication under Art 30 of the Basic Law. While the Executive Order prescribing a new procedure was an improvement over the old regime, it was not in accordance with 'legal procedures' as required by Art 30. The Government argued that if s 33 and the Executive Order were declared unconstitutional, the law enforcement agencies would immediately be left with no power to conduct or continue covert surveillance and there would be disastrous consequences on the maintenance of law and order. As a result, the Court of First Instance (and affirmed by the Court of Appeal) granted an order of temporary validity so that s 33 and the Executive Order remained valid with legal effect for a period of six months so as to afford the Government time to introduce remedial legislation. On further appeal, the Court of Final Appeal set aside the temporary validity order and replaced it with an order to suspend the declaration of inconsistency for the same period of time.

The decision is controversial in two respects. First, it is unclear on what basis can a court claim to have jurisdiction to suspend a declaration or to grant a temporary validity order? Secondly, when could the court ever justify upholding the validity of a legislative provision, even temporarily, when it has unequivocally found the provision to be unconstitutional?

\footnotetext{
$17 \quad R v$ Monopolies and Mergers Commission, ex p Argyll Group Plc [1986] 1 WLR 763; Caswell v Dairy Produce Quota Tribunal [1990] 2 AC 738. (2006) 9 HKCFAR 441.

Secretary for Justice v Shum Chiu [2006] HKEC 2335. See also HKSAR v Chan Kau Tai [2006] 1 HKLRD 400 and HKSAR v Mo Yuk Ping [2005] HKEC 1318; HKSAR v Li Man Tak [2005] HKEC 1309.
} 
Hartmann $J$ (as he then was) rested his case on a general notion of the rule of law. He referred to a number of cases from the Federal Court of Pakistan, the Canadian Supreme Court and the House of Lords, and notably Re Manitoba Language Rights ${ }^{20}$ and held that when the very fabric of the rule of law was threatened, the court would have the power to avoid a situation where there would be no rule of law. This is a rather broad formulation which might not really provide any useful guidance. Given the exceptional nature of this power, it is better that the circumstances and the need for the exercise of such power be more specifically defined. Instead of relying on a general notion of the rule of law to confer temporary validity, the Court of Final Appeal was prepared to rely on an inherent jurisdiction, arguing that 'the power to suspend a declaration is a concomitant of power to make the declaration'. ${ }^{21}$ While this seems to provide a better jurisdictional basis for the exercise of this power, it is unclear if such 'inherent jurisdiction' exists in the first place.

Another way of looking at this issue is to ask if the court can exercise a power of prospective overruling, ie, imposing a temporal restriction on its order so that it would only apply prospectively. ${ }^{22}$ In this regard, the power to suspend a declaration of unconstitutionality so as not to unduly disturb the present and the power to make prospective overruling so as not to jeopardize past events are just two sides of the same coin. The only difference is that in one case the judgment takes effect from the time of the judgment, whereas in the other case the judgment takes effect some time from the judgment. A purely prospective order does not make practical sense, as the applicant in the case must be seeking relief in relation to certain acts that took place in the past. To this extent it may be more accurate to describe it as a 'modified prospective application', namely, that the order will apply prospectively except that it will apply to the immediate parties to the proceedings and, perhaps, parties in other cases that are pending the resolution of the subject proceeding. ${ }^{23}$ Whether there is jurisdiction to make a prospective or modified prospective order is controversial. In some jurisdictions, such as South Africa, India or Scotland, there is an express power in the constitutional instrument to limit the retrospective application of a

$20 \quad$ [1985] 1 SCR 721; (1995) $19 \operatorname{DLR}\left(4^{\text {th }}\right) 1$.

21 See Bokhary PJ, at 456, paras 32-34. See also Bokhary PJ, 'The First Decade of the Basic Law - A Judicial Perspective' (2007) 15(2) Asia Pacific Law Review 125, at133.

22 It can be argued that prospective overruling is more drastic than suspension of declaratory relief, as the latter declaration will still take immediate effect with a temporal limit, whereas a prospective ruling will only take effective some time in the future. As suggested below, such a distinction, if it ever exists, has probably no practical consequences.

23 HKSAR v Hung Chan Wa [2006] HKEC 183, para 12 (CA). See also Dame Mary Arden, 'Prospective Overruling' (2004) 120 LQR 7. It may also benefit those who are still in time to lodge an appeal. 
declaration of inconsistency. ${ }^{24}$ Short of an express statutory power, the starting point is that judgments would always have retrospective and prospective effect, as the court in any judicial decision must necessarily be deciding on the rights and obligations of the parties in relation to events that happened before the action was brought to the court. ${ }^{25}$

\section{Jurisdiction to make prospective overruling}

In Re Manitoba Language Rights case, ${ }^{26}$ the Canadian Supreme Court found the absence of an official French text of the legislation a violation of the equal language rights under the Canadian Charter. The consequence of this finding was that all laws in Manitoba were unconstitutional. Relying on a decision of the Federal Court of Pakistan, ${ }^{27}$ the Canadian Supreme Court held that the dire consequence of wiping out all laws in one stroke justified an exceptional measure of deeming all laws of Manitoba temporarily valid for the minimum period of time necessary for their translation, re-enactment, printing and publication, as it "is only in this way that legal chaos can be avoided and the rule of law preserved." It granted the Government a period of five years to translate and republish all the existing laws. Although the Canadian Supreme Court made reference to a broad notion of the rule of law, namely that to wipe out all laws overnight would be the antithesis of the rule of law, it rested its decision on the doctrine of necessity.

In $R v$ Swain, ${ }^{28}$ the Canadian Supreme Court struck down a provision authorizing automatic detention at the Lieutenant Governor's pleasure of any person acquitted by reason of insanity for being a violation of the right to liberty under the Canadian Charter. As this conclusion could result in the immediate release of all insanity acquittees into the community, the Court accorded six months' suspension of its declaration to allow for the enactment of remedial legislation. Likewise, in Schachter $v$ Canada, ${ }^{29}$ when the Supreme Court struck

\footnotetext{
24 See Scotland Act 1998, s 102 and Constitution of South Africa. In India, it was found that the Indian Constitution did confer such power: see Golak Nath $v$ State of Punjab AIR 1967 SC 1643. A good summary was provided by Stock JA in HKSAR v Hung Chan Wa [2006 HKEC 183, paras 28-29. Kleinwort Benson Ltd v Lincoln County Council [1999] 2 AC 349; Lau Kwong Yung v Director of Immigration (1999) 2 HKCFAR 300 at 326.

$26 \quad$ [1985] 1 SCR 721.

$27 \quad$ Special Reference No 1 of 1995, PLR 1956 WP 598.

28 [1991] 1 SCR 933. See also $R$ v Feeney [1997] 2 SCR 117; [1997] 3 SCR 1008.

$29 \quad$ (1992) 93 DLR $\left(4^{\text {th }}\right) 1$. Interestingly, when the HK Court of Final Appeal held unconstitutional the extension of the eligibility requirement for social welfare be extended to seven years and restored the previous one year's residency requirement, there was no argument or consideration of a suspension of the declaration
} 
down a legislative provision conferring more generous child benefits on adoptive parents for being discriminatory, it was prepared to grant a temporary validity order suspend to allow time for the Government to decide whether to introduce legislation either to remove the benefits for adoptive parents or to extend the benefits to natural parents. Lamer CJ affirmed the power of suspension in rather broad language: ${ }^{30}$

"A court may strike down legislation or a legislative provision but suspend the effect of that declaration until Parliament or the provincial legislature has had an opportunity to fill the void. This approach is clearly appropriate where the striking down of a provision poses a potential danger to the public ( $R v$ Swain) or otherwise threatens the rule of law (Re Manitoba Language Rights). It may also be appropriate to cases of underinclusiveness as opposed to overbreath."

The Court eventually found it unnecessary to make the temporary validity order, but went on to hold that such an order would be justified if striking down a legislative provision would pose a danger to the public, threaten the rule of law or result in the deprivation of benefits.

Despite earlier reservation, ${ }^{31}$ the Canadian court has confirmed that it had a power to make prospective overruling. In Canada v Hislop, the court was concerned with the validity of certain remedial legislation trying to provide equal support obligations, including entitlement to survivor pension, for same-sex relationship and opposite-sex relationships,. ${ }^{32}$ The former law that drew a distinction between these two groups was struck down with effect from 1985 in an earlier case for having violated the equality clause under the Canadian Charter. The remedial law provided that the surviving partners of a same-sex relationship was only entitled to the survivor pension as from the date of the remedial legislation. The Canadian Supreme Court upheld the remedial law, thereby affirming that its earlier decision would only have prospective effect. It held that "the question is no longer the legitimacy of prospective remedies, but rather when, why and how judges may rule prospectively or restrict the retroactive effect of their decisions in constitutional matters." This is a question of

despite the resultant increase in social welfare expenditure: Kong Yunming v Director of Social Welfare [2014] 1 HKC $518 .$.

$30 \quad$ Ibid, at 715 .

$31 \quad$ Edward and Edward (1987) 39 DLR (4 $\left.4^{\text {th }}\right) 654$.

32 [2007] 1 SCR 429 
balancing between the adverse impact on the government and the fairness of restricting the retroactive effect of its judgment on the litigants.

This approach was rejected in Australia on the ground of a separation of powers. It was said that the court would be usurping a legislative power if it could declare what the law was yesterday and what the law is as from today or will be at some time in the future. ${ }^{33}$ The Australia High Court drew a distinction between adjudication of rights, which was the proper role of a court, and creation of rights, which fell outside the remit of the court. It held that the court has no inherent jurisdiction to make a prospective order, and that it would be a perversion of judicial power to maintain in force unconstitutional law, especially when noncompliance with the unconstitutional law exposed one to criminal prosecution. ${ }^{34}$

In contrast, in the United Kingdom, while Lord Goff has suggested barely 10 years ago that prospective overruling has no place in English legal system, ${ }^{35}$ the House of Lords recently held that such a power existed in all situations, but that it could only be exercised in exceptional circumstances. ${ }^{36}$ It cautioned that this power could only be exercised 'where a decision on an issue of law, whether common law or statute law, was unavoidable but the decision would have such gravely unfair and disruptive consequences for past transactions or happenings that the House of Lords would be compelled to depart from the normal principles relating to the retrospective and prospective effect of court decisions. ${ }^{37}$ Likewise, in an earlier judgment, Lord Nicholls remarked obiter that "[i]t may also be that there are circumstances where maintaining an offending law in operation for a reasonable period pending enactment of corrective legislation is justifiable."38 However, Lord Scott and Lord Steyn dissented on the ground that in the absence of legislative authority, a prospective ruling would appear to constitute an improper usurpation by the judiciary of the role of the legislature. ${ }^{39}$ In the more recent decision of HM Treasuryv Ahmed (No 2), the Government asked the court to grant a suspension order staying its order of invalidity of certain subsidiary legislation so as to allow Government time to introduce remedial legislation. The Supreme

\footnotetext{
33 Lord Reid, 'The Judge as Law Maker' (1972-73) 12 JSPTL 22, 23.

$34 \quad H a v$ New South Wales (1997) 189 CLR 465 at 503-4 and 515.

$35 \quad$ Kleinwort Benson Ltd v Lincoln County Council [1999] 2 AC 349 at 379.

$36 \quad$ National Westminster Bank plc v Re Spectrum Plus Ltd [2005] 2 AC 680. It is of interest to note that this is a private law case. The power of prospective overruling has never been invoked since this case.

$37 \quad$ At 699, para 40, per Lord Nicholls.

$38 \quad$ Bellinger v Bellinger [2003] 2 AC 467.

$39 \quad[2005] 2 \mathrm{AC} 680$ at 726 , para 125.
} 
Court refused to grant a suspension order on the ground that it was futile as it could not alter the fact that the subsidiary legislation was ultra vires and void. On the other hand, a suspension order would create a false impression that the impugned subsidiary legislation remained in force. ${ }^{40}$ Taking the reasoning of the majority to its logical end, the court would have no power to breathe life into what has found to be unconstitutional and void. ${ }^{41}$

In the United States, where this power is more enthusiastically invoked, there is a mixed record. The US experience was described by Lord Nicholls in Re Spectrum Plus Ltd as being 'waxed and waned', particularly in the context of criminal law when liberty of the subject is involved. ${ }^{42}$ The court was more ready to apply prospective overruling if the normal retroactive effect would have gravely unfair and disruptive consequences for past transactions or happenings, such as rendering children to a marriage illegitimate by invalidating legislative divorce, ${ }^{43}$ or upset past commercial, property or contractual transactions where clients have relied on their legal advice in conducting their business. ${ }^{44}$ In New Zealand, the power to make prospective overruling was also left open, though Tipping $\mathrm{J}$ and Thomas $\mathrm{J}$ had indicated their acceptance of such power. ${ }^{45}$ Tipping $\mathrm{J}$ held that the power was necessary to balance the harm that might be done on individuals or society when the decision had and when it did not have retrospective effect. In this regard the court developed the notion of reliance, namely, that the unfairness has to stem from popular reliance of the previous state of law that was regarded as settled. Thus, the gradual evolution of the common law will not fall into this category, nor will the law be regarded as settled in the early days of the development of constitutional jurisprudence. ${ }^{46}$ The European Court of Human Rights also seems to have accepted such a power in order to avoid 're-opening legal practice or situations that antedate

\footnotetext{
$40 \quad$ [2010] 2 WLR 378, at 463-464 (Lord Hope dissenting).

41 Forsyth seems to agree that the court should not have a discretion to suspend its invalidity order, though the jurisdictional issue was not really addressed: see C Forsyth, “ The Rock and the Sand: Jurisdiction and Remedial Discretion", a paper presented at the University of Hong Kong, March 2014 (http://papers.ssrn.com/sol3/papers.cfm?abstract_id=2317277., whereas Li argued that the risk of obfuscation was a matter of explanation only: see Li, supra, n 2, at 52.

42 Supra, at 693, paras 18-19. Prospective overruling was upheld in Linkletter $v$ Walker, 381 US 618 (1965), but its application to criminal law was restricted by Griffiths v Kentucky, $107 \mathrm{~S} \mathrm{Ct} 708$ (1987).

$43 \quad$ Bingham v Miller, 17 Ohio 445 (1848)

44 See Traynor, "Quo Vadis, Prospective Overruling: A Question of Judicial Responsibility" (1977) 28 Hasting Law Journal 533 at 543.

45 Lai $v$ Chamberlains [2007] 2 NZLR 7. The majority comprising Elias CJ and Gault and Keith JJfound it unnecessary to decide on this point.

46 See Stock VP, in HKSAR v Hung Chan Wa, CACC 411/2003, [2006] HKEC 183, at paras 35 and 47
} 
the delivery of its judgment. ${ }^{, 47}$ This has gone considerably beyond the restricted situations in Schachter and indicates a greater willingness to grant a temporary validity order. ${ }^{48}$

In Hong Kong, the Court of Final Appeal drew a distinction between a temporary validity order and a stay of a declaration of invalidity. It has left open the question whether the court has jurisdiction to make a temporary validity order, but it appeared to accept that it has such an inherent power to stay a declaration of invalidity. ${ }^{49}$ Bokhary PJ held that "the judicial power to suspend the operation of a declaration is a concomitant of the power to make the declaration in the first place", and hence "there is no need to resort to the doctrine of necessity." ${ }^{50}$ It recognized that this question might depend on the understanding and the extent of separation of powers and the particular relations between the Legislature, the Executive and the Judiciary in different jurisdictions, and as a result, this was not a question that might yield to a common answer in different parts of the common law world.

The power of suspending a declaration of unconstitutionality was exercised again, and was hence implicitly assumed, in $W v$ Registrar of Marriages. ${ }^{51}$ In that case, the issue was whether the definition of male and female in the Marriage Ordinance would include a postoperation gender of a transsexual for the purpose of a marriage. The Court of Final Appeal held that the definition should be read to recognize a post-operation gender, but in view of the possible difficult issues that could arise, it was prepared to suspend the declaration for 12 months allow an opportunity for the Government and the legislature to consider enacting legislation to deal with such issues. The Court event went on at some length to highlight these potentially difficult legal issues that would have to be addressed. ${ }^{52}$

\section{Temporary Validity v Suspension}

\footnotetext{
$47 \quad$ Marckx $v$ Belgium (1979) 2 EHRR 330 at 353. See also a similar approach adopted by the European Court of Justice: $R$ (on the application of Bidar) $v$ Ealing LBC, Case C-209/03

48 Li noted the increasing readiness on the part of the Canadian courts to adopt prospective overruling or grant temporary validity order after 1999: see Li, n 2 above, at 35.

$49 \quad$ HKSAR v Hung Chan Wa (2006) 9 HKCFAR 614.

$50 \quad$ Koo Sze Yiu v Chief Executive of the HKSAR (2006) 9 HKCFAR 441 at 456, para 34. The court, however, left open the question whether it had jurisdiction to make an order of temporary validity: see para 32.

51 (2013) 16 HKCFAR 112. See also Chan Kin Sum v Secretary for Justice [2009] 2 HKLRD 166 and Li, supra, n 2, at 50 and the cases referred to at fn 98 .

52 Ibid, at paras 129-148.
} 
In the Koo Sze Yiu case, the Court of First Instance made a "temporary validity order" pending corrective legislation for a six-month period. The Court of Final Appeal, however, substituted a suspension of the declarations of unconstitutionality so as to postpone their coming into operation for six months. It drew a distinction between temporary validity order and a suspension of a declaration and emphasized that the level of necessity required for suspension was substantially lower than that required for a temporary validity. It is doubtful if this distinction is sound. Be it a temporary validity order or a suspension, the practical result is the same that an otherwise unconstitutional legislative provision is allowed to continue to operate, albeit for a definite period of time. In both cases this can only be justified on very compelling grounds. Thus, it would be difficult to see, conceptually and practically, what difference there would be between temporary validity and suspension. It is more likely that they are just different ways of putting the same idea.

The Court suggested that a temporary validity order shields the executive from legal liability while acting under the unconstitutional law, whereas the executive has no such shield under a suspension. While such a distinction is arguably valid, it is of doubtful practical value. In the context of covert surveillance, most people under surveillance would not be able to find out that they have been subject to such surveillance, let alone to bringing an action for damages or injunction. Injunctive relief is unlikely to be available, as an injunction is contrary to the grant of a stay of declaration in the first place. The only other possible remedy is a claim for damages, but why should the Government be liable for substantial compensation for doing something that the Court is prepared to tolerate on strong public interest ground $?^{53}$ If damages were available, they are unlikely to be anything other than nominal.

\section{"The Most Extraordinary Circumstances"}

As the power should only be exercised in the most extraordinary circumstances, it is doubtful if this case falls within the category of "the most extraordinary circumstances" In Schachter $v$ Canada, it was suggested that a temporary validity order would only be made where the immediate striking down of the law would (1) pose a danger to the public; (2) threaten the rule of law; or (3) result in the deprivation of benefits from deserving persons,

53 See also Yap Po Jen, 'Constitutional Review under the Basic Law: The Rise, Retreat and Resurgence of Judicial Power in Hong Kong' (2007) 37(2) HKLJ 449 at 470-471. 
though these categories are not exhaustive. ${ }^{54}$ The Hong Kong courts seem to have gone well beyond these restricted categories. In Koo Sze Yiu v Chief Executive of the HKSAR, the Government argued that the legal vacuum arising from the striking down of the provision authorizing covert surveillance would mean that it would be unlawful for the law enforcement agencies to conduct covert surveillance, and this consequence would have disastrous results. The Applicants, however, replied that if there was to be a crisis, it would be of the Government's own making. ${ }^{55}$ The Government was fully aware, at least since the Bill of Rights came into force in 1991, that s 33 would likely be unconstitutional, since a similar provision in the English Act has been declared by the European Court of Human Rights to be in violation of Article 17 of the European Convention of Human Rights. ${ }^{56}$ In the late 1996, the Law Reform Commission concluded that s 33 was inconsistent with Article 17 of the ICCPR and therefore unconstitutional. When the Government was unmoved, a private member's bill amending s 33 was successfully introduced on 27 June 1997, despite the strong opposition of the Government. Given that the Government needed to modify its own internal process on surveillance, it was agreed that the bill would only come into effect on a day to be appointed by the Government, which had never appointed such a date. It was only when the District Court declared inadmissible certain evidence obtained from covert surveillance that the Government was finally moved to action. Even so, it refused to bring the amended legislation into force or to introduce new legislation. Instead, it introduced an Executive Order, which was subsequently found by the Court that such Executive Order did not constitute a set of "legal procedure" for the purpose of Article 30 of the Basic Law and hence the authorization of covert surveillance was unconstitutional. In such circumstances, the Applicants argued, that if the law enforcement agencies were put in a difficult position to detect and investigate crimes, the Government has only had itself to blame. Besides, it could not constitute "the most extraordinary circumstances" when the option of giving effect to the amended legislation in 1996 was open to the Government. Its refusal to accept an amendment should not be a sufficient ground to suspend a declaration. The amendment bill

$54 \quad$ (1992) $93 \operatorname{DLR}\left(4^{\text {th }}\right) 1$ at 26.

55 In late 1996, the Law Reform Commission concluded that s.33 was inconsistent with Article 17 of the ICCPR and therefore unconstitutional. A private member's bill amending s.33 was successfully introduced in June 1997 despite the Administration's opposition. The Applicants contended that the Chief Executive, acting on the advice of the Administration, had never intended to bring the Ordinance into operation and the Ordinance had yet to commence after 8 years. The Executive Order subsequently made by the Chief Executive, however, did not constitute a set of "legal procedures" for the purpose of Article 30 of the Basic Law and was therefore unconstitutional. In such circumstances, the Applicants argued that if the law enforcement agencies were put in a difficult position to detect and investigate crimes, the Government had only had itself to blame. 
may not be the ideal solution and may be inconvenient to the Government, but it did provide an alternative and mere inconvenience to the Government should not be a sufficient justification to suspend a declaration, thereby allowing the offending law to continue to operate. These are powerful arguments, but they did not prevail and the Court of Final Appeal affirmed the suspension of the declaratory relief. ${ }^{57}$ Sir Anthony Mason did accept that the level of necessity was relatively low in that case, but he tried to justify this low level of necessity by reverting to the distinction between temporary validity and suspension. ${ }^{58}$ Ironically, it only served to highlight the unsatisfactory nature of this distinction as its only result is to lower the requirements for extraordinary circumstances, which is required even for an order of suspension.

In the $W$ case, there was little discussion about the need to suspend the declaration. ${ }^{59}$ It seems that the Court readily accepted that it was necessary to grant time for the Government to introduce necessary legislation to deal with issues such as how to define a post-operation gender that qualifies for marriage purpose, what impact it would have on an existing marriage and the children to the existing marriage when one of the parties to the marriage has undergone a gender re-assignment surgery. While these are all legitimate concerns which would have to be addressed, the Court did not seem to have applied its mind to how these problems were over and above what would normally be expected in a controversial decision of significant implications for the community. The Court may be right at the end of the day to grant the suspension, but the absence of any discussion on how to exercise this extraordinary power appears to suggest that the Court has not imposed a high threshold to satisfy itself of what constitutes "the most extraordinary circumstances".

\section{Conclusion}

It is argued that the existence of a power to make prospective overruling is ultimately a matter of achieving competing notions of justice. The court has to balance, on the one hand, the logical consequence of a finding of illegality as a matter of the rule of law, and on the

\footnotetext{
57 Ibid, at para 42. The Court relied on three reasons: (1) the amendment bill covers only interception of communications by post or telecommunication and did not extend to covert surveillance in all its possible aspects; (2) it would take time to introduce subsidiary legislation to make the amendment bill workable; (3) this would amount to an indirect enforcement to bring the amendment bill into operation, which relief has been refused. While bringing into force the amendment bill may bring inconvenience to the Government, it did not mean that the Government could not operate without a suspension.

$58 \quad$ Ibid, at para 60.

59 (2013) 16 HKCFAR 112.
} 
other hand, the disruptive effect of a finding of unconstitutionality on the wider community. As it is familiar in administrative law, a court may sometimes refuse relief because no injustice has been done and the grant of relief would not be conducive to good administration or would unfairly upset vested rights of third parties. Likewise, there must be cases where injustice would result if a declaration of invalidity is allowed to operate retrospectively. Legal certainty is particularly important in private law matters such as land, contract or property. There may be undesirable economic repercussions if decisions relying on a statutory provision which has since been declared unconstitutional would upset such decisions in the past. ${ }^{60}$ Likewise, if a legislative provision on divorce is struck down with retrospective effect, it may result in numerous cases of illegitimate births which are otherwise legitimate. ${ }^{61}$ In some of these cases, the principle that vested rights should not be affected may come to an aid to avoid such undesirable consequences, but this may not work in all cases, such as a situation when there would be a legal vacuum or extraordinary administrative dislocation as in Re Manitoba Language Rights or allegedly in Koo Siu Yiu. On the other hand, prospective overruling may cause injustice when liberty of the person is at risk. This is particularly the case when someone whose liberty is deprived of by an impugned legislative provision in a criminal process is denied the benefit of a declaration of unconstitutionality. This may have to be balanced against the desirability of finality in criminal law. ${ }^{62}$ On the whole, it seems that the case for the existence of such a power is overwhelming, so long as it is a power that could only be exercised in extraordinary circumstances and would probably only as a means of last resort.

Even if such a power exists, its exercise may vary depending on the issues. For instance, in statutory interpretation, under the declaratory theory, an interpretation by the judiciary will relate back to the time when the legislation was first enacted and therefore a prospective order in the context of statutory interpretation would not be appropriate. ${ }^{63}$ Lord Steyn and Lord Scott held the same view in their dissenting judgment in this regard in $R e$ Spectrum Plus Ltd. ${ }^{64}$ On the other hand, it was argued that the declaratory theory had no

\footnotetext{
$60 \quad$ Hill v Atlantic, 55 SR 854 (1906).

$61 \quad$ Bingham $v$ Miller, 17 Ohio 445 (1848).

$62 \quad$ Compare $R v$ Kwok Hing Man (1994) 4 HKPLR 186 and HKSAR v Hung Chan Wa (2006) 9 HKCFAR 614. See also Lord Nicholls in Re Spectrum Plus Ltd, at 696, paras 26-27. Kleinwort Benson Ltd v Lincoln County Council [1999] 2 AC 349; Lau Kong Yung v Director of Immigration (1999) 2 HKCFAR 300 at 326; National Westminster Bank plc v Spectrum Plus Ltd [2005] 4 All ER 209 at 225 National Westminister Bank plc v Spectrum Plus Ltd [2005] 2 AC 680.
} 
place when there was a new constitution under which previous law was adopted save to the extent of inconsistency with the new constitution. This is the situation under the Basic Law. Under Art 160 of the Basic Law, any pre-existing law that is discovered to be inconsistent with the Basic Law after the Basic Law has come into effect shall cease to have force. It was argued that the effect of any order of inconsistency could, as mandated by Art 160, only be prospective as from the date when the law was declared unconstitutional. It followed, as contended, that convictions made pursuant to a statutory provision before that statutory provision was held unconstitutional should not be affected by the court's declaration of unconstitutionality. This argument was rejected by the Court of Appeal as it would lead to illogical and absurd consequences. If Art 160 mandates prospective overruling, it creates an illogical distinction between pre-1997 and post-1997 laws. In any event, many legislative provisions that are inconsistent with the Basic Law may also be inconsistent with the ICCPR as applied to Hong Kong, and would have been repealed by the Bill of Rights Ordinance before 1 July 1997 (if it was enacted before 1991) or prevented from coming into force by the Letters Patent (if it was enacted after 1991 but before 1 July 1997). In either case, such impugned statutory provision would not have formed part of the pre-1997 laws and would therefore not have been adopted in the HKSAR. The Court of Final Appeal, however, rested its decision on the basis that Art 160 applied only to legislation and not judicial decision. ${ }^{65}$

In conclusion, it is submitted that the Court does enjoy a power to make prospective overruling. However, it is an extraordinary power that the court would approach its exercise with the greatest circumspection. Mere inconvenience is not sufficient, and the court must be satisfied that the consequences of a declaration of unconstitutionality are so disruptive that could not be contained by normal administrative or other measures. The existence and scope of such power may vary in different situations, as the same considerations do not apply to all situations in the different context of private law, criminal law or public law. The court should not exercise such power if it may result in creating a criminal offence which did not exist in the past, or in depriving a person of his liberty for an offence which did not exist or otherwise putting in peril the liberty of a person, and should be vigilant in exercising this power when

65 At 629-630, paras 7-14. The Court of Final Appeal held that the phrase 'shall be amended or cease to have force' once the pre-1997 law was found to be in contravention of the Basic Law suggested that Art 160 applied only to legislative process. This begs the question of how the inconsistency was found in the first place. In most cases the inconsistency is discovered only in the judicial process and one may find it strange that Art 160 would not apply to the most usual situations where inconsistency is found. 
the rights of a third party are affected. On the other hand, the court should be more willing to exercise this power of prospective overruling when not to do so would create unacceptably disruptive consequences to the community. In considering whether to exercise this power, the court may also take into account the range of remedies that may be available. ${ }^{66}$ It is ultimately a pragmatic question of balancing the harm to society or individuals if the decision is given its normal retroactive effect, and the harm or injustice to individuals or society if the effect of the decision is limited to the future. Finally, the time for suspension should not be longer than necessary, for an unduly lengthy suspension will defeat the declaration of unconstitutionality. ${ }^{67}$ On these principles, it appears that the Hong Kong courts have been exercising this discretion in a fairly liberal manner. 